\title{
suPAR: The molecular crystal ball
}

\author{
Maria Thun $\varnothing^{\mathrm{a}}$, Betina Macho ${ }^{\mathrm{a}}$ and Jesper Eugen-Olsen ${ }^{\mathrm{b}, *}$ \\ ${ }^{a}$ Virogates A/S, blokken 45, DK-3460 Birker $\phi d$, Denmark \\ ${ }^{\mathrm{b}}$ Clinical Research Centre, Copenhagen University Hospital, Hvidovre hospital, 2650 Hvidovre, Denmark
}

\begin{abstract}
Plasminogen Activator Receptor (suPAR) levels reflect inflammation and elevated suPAR levels are found in several infectious diseases and cancer. suPAR exists in three forms; suPAR $\mathrm{R}_{\mathrm{I}-\mathrm{III}}$, suPAR $\mathrm{R}_{\mathrm{II}-\mathrm{III}}$ and suPAR ${ }_{\mathrm{I}}$ which show different properties due to structural differences. Studies suggest that full-length suPAR is a regulator of uPAR/uPA by acting as uPA-scavenger, whereas the cleaved suPAR $\mathrm{RI}_{\text {IIII }}$ act as a chemotactic agent promoting the immune response via the SRSRY sequence in the linker-region. This review focus on the various suPAR fragments and their involvement in inflammation and pathogenic processes. We focus on the molecular mechanisms of the suPAR fragments and the link to the inflammatory process, as this could lead to medical applications in infectious and pathological conditions.
\end{abstract}

$\begin{array}{ll}\text { Abbreviations } & \\ \text { uPA: } & \text { urokinase plasminogen activator } \\ \text { uPAR } & \text { uPA receptor } \\ \text { suPAR: } & \text { soluble uPAR } \\ \text { GPI: } & \text { glycosyl-phosphatidylinositol } \\ \text { 7TM: } & \text { seven-trans-membrane } \\ \text { PI-PLD: } & \text { GPI-specific phospholipase-D type } \\ & \text { enzyme } \\ \text { PI-PLC: } & \text { phosphatidylinositol-specific } \\ & \text { phospholipase-C } \\ \text { SAPS II: } & \text { simplified acute physiology score II } \\ \text { SOFA: } & \text { sequential organ failure assessment } \\ \text { SDS-page: } & \text { sodium dodecyl sulfate polyacryl- } \\ & \text { amide gel electrophoresis } \\ \text { PTX: } & \text { pertussis toxin } \\ \text { HAART: } & \text { highly active anti-retroviral therapy } \\ \text { MMPs: } & \text { metalloproteinases } \\ \text { SIRS: } & \text { systemic inflammatory response syn- } \\ & \text { drome } \\ \text { PNH: } & \text { paroxysmal nocturnal hemoglobin- } \\ & \text { uria } \\ \text { ROC: } & \text { receiver operating characteristic } \\ \text { MMP-12: } & \begin{array}{l}\text { human macrophage elastase } \\ \text { phorbol 12-myristate 13-acetate }\end{array} \\ \text { PMA: } & \text { tuberculosis } \\ \text { TB: } & \end{array}$

*Corresponding author. E-mail: jeo@virogates.com.
FPRL1: FPR-like receptor 1

ATF: amino-terminal fragment of the uPA molecule.

\section{Introduction}

suPAR (NCBI Accession no. AAK31795) is the soluble form of the urokinase-type plasminogen activator receptor (uPAR) which is a glycosyl-phosphatidylinositol (GPI)-linked membrane protein. uPAR consists of three domains and is present on various immunologically active cells including monocytes, activated Tlymphocytes and macrophages but also on endothelial cells, keratinocytes, fibroblasts, smooth muscle cells, megakaryocytes and certain tumor cells [22,27,30,33].

Soluble uPAR (suPAR) originates from cleavage and release of the membrane-bound UPAR, and is present in plasma, urine, blood, serum and cerebrospinal fluid [23, $39,93,100,113]$ in various concentrations depending on the "activation" level of the immune system. Increased activation of the immune system leads to increased serum suPAR levels, which has been documented in several pathological conditions, including paroxysmal nocturnal hemoglobinuria, human immuno-deficiency virus type 1 (HIV-1)-infection, malaria, pneumococcaland streptococcus pneumonia bacteraemia, sepsis, bacterial and viral CNS infection, active tuberculosis (TB) and also in various forms of solid tumors, e.g. non- 
small cell lung cancer, breast-, colorectal-, prostateand ovarian cancer $[28,46,59,65,68,84,89,92,95,100$, $101,111,113]$. Furthermore, high blood concentrations of suPAR independently predict high mortality in both patients and healthy individuals [28]. The direct biochemical and molecular background for these observations is still not clear, and it will be important to understand the molecular mechanisms and the link to the inflammatory process, as this could lead to important medical applications in infectious and inflammatory diseases.

This review aims to explore the potential of suPAR as a general marker of disease progression, prognosis and mortality by providing an understanding of the biochemical background and molecular mechanism of suPAR's action in inflammation and infection. We summarize findings from a multitude of studies including the discovery of suPAR, its increase in various disease states and the prognostic implications, as well as the link to the inflammatory reaction. As cleavage of this receptor is believed to be a key event in the accumulation of different fragments, the crystal structure and natural cleavage sites in the protein are reviewed, and form the basis for a discussion about the biochemical significance of the different suPAR-variants. During the last decade, vitronectin and its involvement in cell adhesion and signaling has been given ample attention and we will thus discuss the suggested interaction between suPAR and vitronectin and the potential biomechanistic consequences.

\subsection{The discovery of SUPAR}

The biological function of suPAR has been intensively studied since 1991 where Ploug et al., found that soluble uPAR obtained from phorbol 12-myristate 13acetate (PMA)-stimulated U937 cells expressed high affinity towards uPA. By treating U937 cells with bacterial phosphatidylinositol-specific phospholipase-C (PIPLC) the diacylglycerol portion of the GPI-anchor was removed resulting in a soluble, hydrophilic form of UPAR. Furthermore, a natural release of the receptor into the serum-free medium was also found, although the molecular basis underlying this observation could not be explained. The calculated mass of the soluble protein was $60 \mathrm{kDa}$, which correlates with the calculated mass for the highly glycosylated, membrane-bound uPAR [62,73].

Later that year, a part of the same group published data obtained using a mutant soluble uPAR expressed in mouse LB6 cells, on the mechanism of uPA in physio- logical and pathological invasive processes [56]. These experiments were carried with the therapeutical aim of blocking or decreasing cancer cell invasion. A soluble form of uPAR was constructed through removal of the hydrophobic carboxyl terminus that constitutes the membrane-anchoring capacity in order to interfere with the binding of uPA to the cellular receptor by competitive inhibition of UPAR. Masucci et al., demonstrated that the soluble receptor retained its ability to specifically bind uPA in vitro and they suggested this to act as a uPA-scavenger with possible implications of inhibiting cancer-promoting actions i.e. proteolysis, cell migration and proliferation [56].

The constructed soluble uPAR was intended as a tool to further investigate the mechanisms of the UPA/uPAR system in uPA-dependent proteolysis, plasminogen activating pathway and cancer, but in 1992 Ploug and coworkers focused their work instead on the natural shedding and release of uPAR. Peripheral blood leukocytes from patients affected by the hematologic stem-cell disorder, paroxysmal nocturnal hemoglobinuria (PNH), are characterized by lack of UPAR on differentiated cells surface, which was found not to be due to a similar reduction in the level of specific mRNA. This made Ploug et al., further investigate the presence of UPAR in both cells and conditioned medium. By analyzing blood samples from patients affected by PNH they discovered a soluble, hydrophilic uPAR but found no shedding of the receptor under normal conditions [74]. They suggested that UPAR is shed from the membrane and that the soluble form retains its ligand-binding capability, thus confirming earlier results [56,73,74]. Rønne et al., was the first group to discover the soluble receptor in plasma from healthy individuals and suggested that the soluble uPAR found in this plasma reflects the overall level of activity of the uPAR-mediated cell surface proteolysis [84]. Extensive research has shown that the receptor found in plasma and serum can exist in various cleaved forms, which will be discussed in detail below. Wahlberg et al., was the first group to demonstrate the existence of cleaved suPAR in cystic fluids. This cleaved receptor constitutes only two domains and will be referred to as suPAR $\mathrm{II}_{\text {-III }}$ [103].

These early studies have led to continuing investigations of the biochemical mechanisms of both the membrane oriented uPA/uPAR system as well as the soluble forms of the receptor. Conclusions from these studies have a high degree of variability and suggest suPAR to exert a variety of functions and to be involved in numerous physiological pathways, including the plasminogen activating pathway, inflammation, modulation of cell adhesion, migration and proliferation $[28,46,65,72,89$, $111,113]$. 


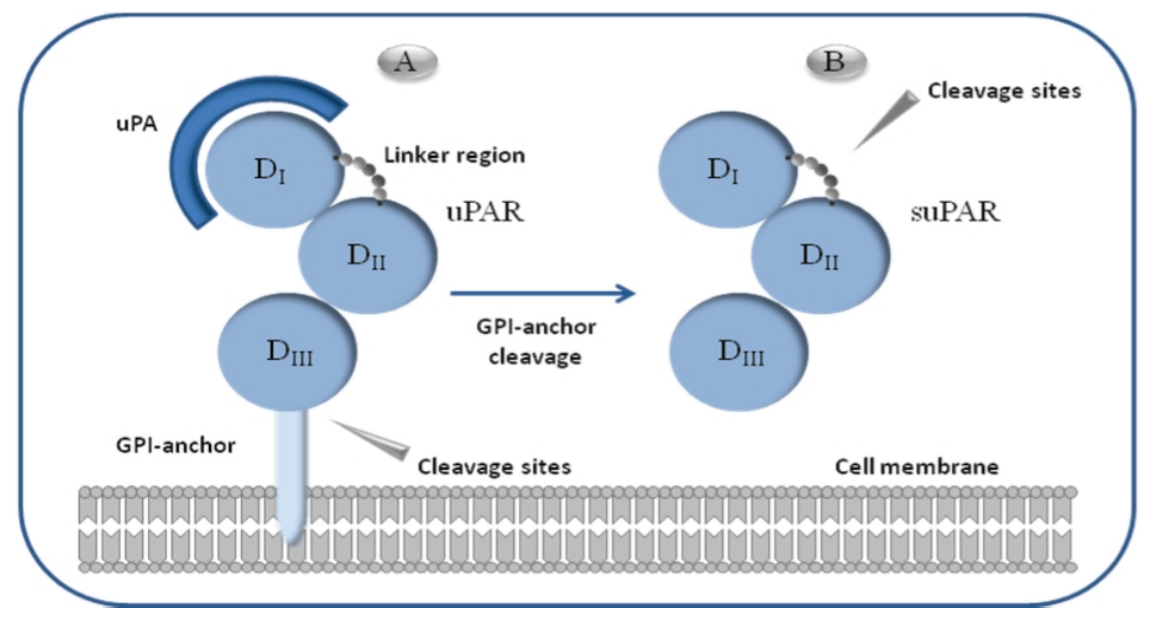

Fig. 1. Schematic representation of membrane-bound and soluble urokinase receptor. The GPI-anchor links uPAR to the cell membrane making it available for uPA binding (A). When the receptor is cleaved between the GPI-anchor and $\mathrm{D}_{\text {III }}$, it becomes soluble (B). suPAR is a stable protein that can be measured in various body fluids. uPA: urokinase-type plasminogen activator, uPAR: uPA receptor, suPAR: soluble uPAR.

\subsection{Localization}

suPAR is the soluble form of the urokinase-type plasminogen activator receptor (uPAR) which is a GPIlinked membrane protein (Fig. 1.A). The GPI-anchor is composed of a lipid moiety linked to the protein through a phosphodiester bond and a carbohydrate moiety [73]. As illustrated in Fig. 1.B, suPAR is released from the cell membrane by cleavage between this membrane-anchoring GPI-molecule and the attached domain $\left(\mathrm{D}_{\mathrm{III}}\right)$. In its membrane-bound form it is present in various immunologically active cells including monocytes, activated T-lymphocytes and macrophages, but also endothelial cells, keratinocytes, fibroblasts, smooth muscle cells, megakaryocytes and certain tumor cells $[22,27,30,33]$. In its soluble form it is found in various body fluids, including plasma, urine and cerebrospinal fluid. Sidenius et al., documented the existence of full-length suPAR in serum from healthy individuals confirming earlier results but in addition to the full-length suPAR the group also identified two cleaved soluble forms (suPAR $_{\mathrm{II}-\mathrm{III}}$ and suPAR $\mathrm{R}_{\mathrm{I}}$ ) in urine [90].

In healthy individuals, suPAR levels are quite stable in both blood and urine and suPAR levels in urine, adjusted according to urine creatinine, correlates positively and strongly with plasma suPAR-levels in healthy individuals, patients suffering from malignant cancers, and HIV-infected patients on stable highly active antiretroviral therapy (HAART) $[3,60,93]$. Circadian suPAR plasma-concentrations (measured $24 \mathrm{hr}, 20 \mathrm{~min}-$ intervals) appear to be stable [3]. suPAR concentra- tions show a significant positive correlation with age [3] and a gender-specific variation where slightly higher concentrations are present in serum from females compared to males [100].

\subsection{Genetic origin and primary structure}

The gene for uPAR (PLAUR; HGNC accession number: 9053) maps to chromosome 19q13.2 and consists of 7 exons and 6 introns [12,16,105]. In vitro studies have situated the transcription start site 52 bp upstream to the translation start site (ATG), which is illustrated on Fig. 2.

The promoter activity is primarily restricted to a fragment located $-401 \mathrm{bp}$ to $+46 \mathrm{bp}$, with the basal promoter activity restricted to a fragment located $-141 \mathrm{bp}$ to +47 bp relative to the transcription start site $[20,98]$. The promoter contains a number of regulatory sites including AP1, AP2, SP1, NFkB and PEA3 sites [1,20, $37,50,98,106]$.

The gene is translated into a 313 -amino acid single polypeptide sequence containing three repeats; $\mathrm{D}_{\mathrm{I}}, \mathrm{D}_{\mathrm{II}}$ and $\mathrm{D}_{\text {III }}$ (residues 1-92, 93-191, and 192-282, respectively) characterized by a unique pattern of cysteine residues (see Fig. 3) [82]. The presence of the three repeats in UPAR suggests that the receptor arose as a result of internal triplication of an ancestral domain [8].

In the alignment of cDNA sequences of the three domains, $\mathrm{D}_{\mathrm{I}}$ appears to be more distantly related to $\mathrm{D}_{\mathrm{II}}$ and $\mathrm{D}_{\mathrm{III}}$. Sequences of $\mathrm{D}_{\mathrm{II}}$ and $\mathrm{D}_{\mathrm{III}}$ show $22 \%$ identity; all the 10 cysteines of the second repeat align with the 10 cysteines of the third repeat. $\mathrm{D}_{\text {I }}$ shows $16 \%$ 


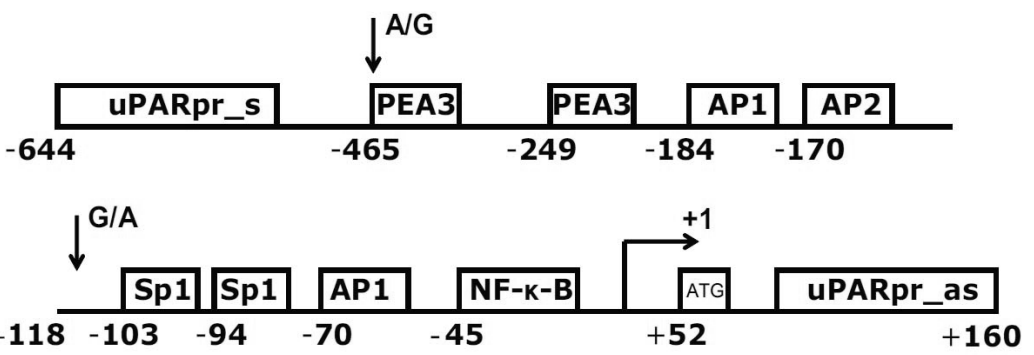

Fig. 2. The uPAR promoter. The promoter from $-644 \mathrm{bp}$ to +160 relative to the transcription start site with known regulatory sites and the two identified transitions [85].

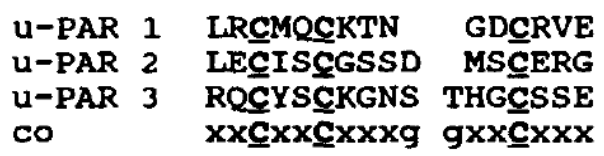

ECALGQDLCRTTIVRLWEEGEELELVEKSCTHS RHQSLQCERSPEEQCELDVVTHWIQEGEEGRPKDDRHLRG ETFLIDCRGPMNQCLLVATGTH EPKNQSYMVRG

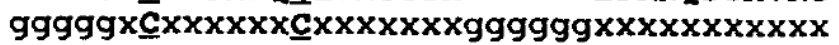

Fig. 3. Internal amino acid sequence repeats of uPAR. Cysteine residues are underlined. uPAR 1: $D_{I}$, uPAR 2: DII, uPAR 3: DIII, co: consensus sequence for the three repeats of uPAR. Anchor denotes the attachment sites for GPI-anchor. Arrow denotes the start of a chemotactic epitope in the linker region. Sequence obtained from $[8,82]$.

and $12 \%$ identity with the $\mathrm{D}_{\mathrm{II}}$ and $\mathrm{D}_{\mathrm{III}}$, respectively [8]. As will be discussed below, $\mathrm{D}_{\mathrm{I}}$ is not only distinct from $\mathrm{D}_{\text {II }}$ and $\mathrm{D}_{\text {III }}$ on the primary structure level, but also in its tertiary structure as a mature protein-fragment $\left(\right.$ suPAR $\left._{\mathrm{I}}\right)$ where it shows distinct binding properties of ligands compared to $\mathrm{D}_{\mathrm{II}}$ and $\mathrm{D}_{\mathrm{III}}$.

\subsection{Crystal structure of suPAR}

During posttranslational modification, approximately 30 residues are removed [73] and a GPI-anchor is added to the C-terminal at Gly283 (see Fig. 3), which is cleaved off in the soluble form of the receptor. The amino acid sequence for human UPAR/suPAR contains five N-linked glycosylation sites affecting the molecular mass of these proteins. Several differently glycosylated variants have been reported among different cell types [7,62]. In sodium dodecyl sulfate polyacrylamide gel electrophoresis (SDS-page), suPAR is identified as a smear with an apparent molecular mass of 55-60 kDa, but after deglycosylation the apparent molecular mass is $35 \mathrm{kDa}$, which is much lower than most cellular receptors $[7,52,62,112]$.

suPAR consists of three homologues domains $\left(\mathrm{D}_{\mathrm{I}}\right.$, $\mathrm{D}_{\mathrm{II}}$, and $\mathrm{D}_{\mathrm{III}}$ ) with a secondary structure of 17 anti parallel $\beta$-strands with three short $\alpha$-helices as illustrated in Fig. 4. The crystal structure of suPAR in complex with the uPA amino-terminal fragment (ATF) reveals that each of the three domains adopts a typical three-finger fold with three adjacent loops and a small C-terminal loop [39].

The $\mathrm{D}_{\mathrm{I}}$ domain is composed of six $\beta$-strands, which includes the highly conserved $\beta 5$-strand critical in $\mathrm{D}_{\mathrm{I}^{-}}$ $\mathrm{D}_{\text {II }}$ association [52]. $\mathrm{D}_{\text {II }}$ forms a $\beta$-sheet with six $\beta$ strands and a short $\alpha$-helix while $\mathrm{D}_{\text {III }}$ contains only five $\beta$-strands and two $\alpha$-helices. The $\beta 11$ and $\beta 12$ of the $\mathrm{D}_{\text {II }}$ domain form a large interface with $\mathrm{D}_{\text {III }}$ and are thus essential in $\mathrm{D}_{\mathrm{II}}-\mathrm{D}_{\mathrm{III}}$ association. Three hydrogen bonds are formed between the $\mathrm{D}_{\text {III }}$ and the $\mathrm{D}_{\mathrm{I}}$ domains. The structures involved in the interface are the loop (res 226-237) and the $\alpha 3$ helix of $\mathrm{D}_{\text {III }}$ and the loop (residue 47 to 53) of the $\mathrm{D}_{\mathrm{I}}$ domain. Furthermore, the linker region connecting $\mathrm{D}_{\mathrm{I}}$ and $\mathrm{D}_{\mathrm{II}-\mathrm{III}}$ is protease sensitive and thus an important sequence in suPAR's molecular regulation.

\subsection{Conformational change and protein dynamics}

The domains of suPAR are assembled in a righthanded orientation generating a concave shaped recep- 

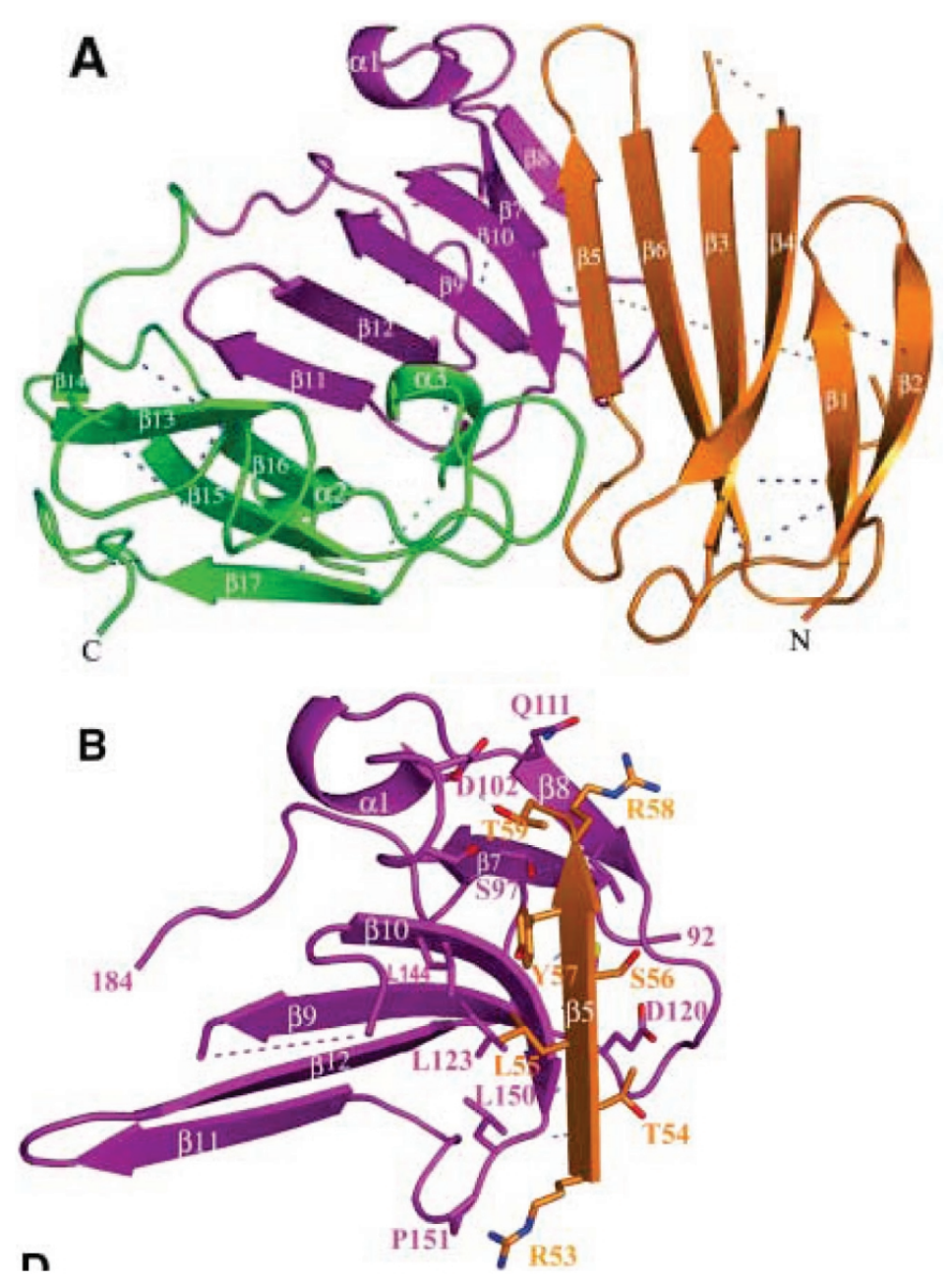

Fig. 4. The structure of human suPAR in complex with ATF illustrated as a ribbon diagram. The suPAR domains are assembled in a right-handed orientation and are colored orange $\left(\mathrm{D}_{\mathrm{I}}\right)$, magenta $\left(\mathrm{D}_{\mathrm{II}}\right)$ and green $\left(\mathrm{D}_{\mathrm{III}}\right)$. $\mathrm{D}_{\mathrm{I}}$ is illustrated with residues $1-80$ and contains six $\beta$-strands. The $\beta 5$ strand in $\mathrm{D}_{\mathrm{I}}$ is highly conserved and is central in association between $\mathrm{D}_{\mathrm{I}}$ and $\mathrm{D}_{\mathrm{II}}$. Residues involved in $\mathrm{D}_{\mathrm{I}}-\mathrm{D}_{\mathrm{II}}$ interaction are shown as sticks in Fig. 4.B. The $\mathrm{D}_{\text {II }}$ domain is illustrated with residues $93-191$ arranged into six $\beta$-strands and a short $\alpha$-helix, and $\mathrm{D}_{\text {III }}$ consists of residues 192-277 containing five $\beta$-strands and two $\alpha$-helices. From [39]. Reprinted with permission from AAAS.

tor with a space between $\mathrm{D}_{\mathrm{I}}$ and $\mathrm{D}_{\mathrm{III}}$. This topology creates a central cone-shaped cavity with a wide opening surrounded by the tips of eight of the nine loops. By superimposing the structure of $\mathrm{D}_{\text {II-III }}$ domains with suPAR in complex with a small peptidyl inhibitor, Huai et al., found that the $\mathrm{D}_{\mathrm{I}}$ domain showed a rotation of $20.5^{\circ}$, while the $\mathrm{D}_{\mathrm{II}-\mathrm{III}}$ domains remained in the same orientation suggesting high flexibility of suPAR interdomain organization $[39,112]$. It has been shown that suPAR and UPAR have slightly different conformations and that this might affect the cleavage of the linker region $[2,43,76]$. This difference is caused by the GPIanchor attached to $\mathrm{D}_{\text {III }}$ of UPAR and removal of the GPI-anchor has been reported to alter the conformation of the protein [43]. The conformational change does not occur within the three domains but rather in the linker region connecting the $\mathrm{D}_{\mathrm{I}}$ with $\mathrm{D}_{\mathrm{II}-\mathrm{III}}$. Monoclonal antibodies raised against human and murine suPAR and UPAR, with epitopes located within the domains, all detect suPAR and UPAR with similar efficiency [51, 71,83 ]. However, an antibody raised to a peptide comprising residues 84-94, which constitutes a part of the linker-region, recognizes uPAR but not suPAR [43]. Thus, the general accessibility of this region is altered in suPAR compared to UPAR. Both receptor-forms have complex oligomeriztion patterns dependent on ligand binding, location of the membrane-bound UPAR on the cell-surface, and other receptor binding molecules like vitronectin, as further discussed below. 


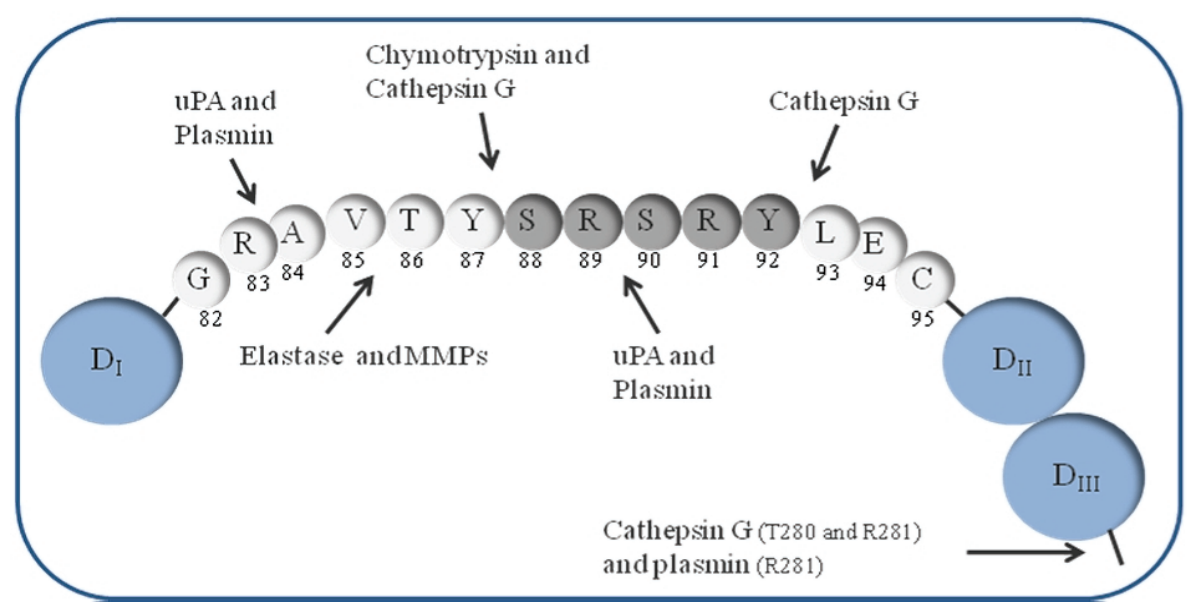

Fig. 5. Schematic illustration of the uPAR linker region and the cleavage sites. The sequence between $\mathrm{D}_{\mathrm{I}}$ and $\mathrm{D}_{\mathrm{II}-\mathrm{III}}$ is illustrated showing the cleavage sites for chymotrypsin, metalloproteinases (MMPs), elastase, cathepsin G, plasmin and uPA. Grey residues illustrate a chemotactic epitope (see also Fig. 3) [3,6,40,41]. Figure created based on [29].

\subsection{Cleavage and regulation}

Cleavage of full-length uPAR/suPAR is well documented in the literature and various fragments have been used extensively in functional studies of the receptor. Regulation of uPAR/suPAR and downstream signaling events on the other hand still remain fairly elusive. Past studies reveal unconnected clues rather than a comprehensive picture. Whereas uPAR expression is highly regulated at the transcriptional level by cytokines and hormones, cellular UPAR protein levels do not strictly correlate with mRNA levels, suggesting posttranscriptional and posttranslational regulation of the receptor mRNA or receptor protein, respectively $[17,19,53,63,87,110]$.

Wilhelm et al., documented a positive correlation between GPI-specific phospholipase-D (GPI-PLD) and release of uPAR in ovarian cancer cells. To determine whether suPAR was derived from the cell surface pool of UPAR, or if it represented a secretory receptor isoform, Wilhelm et al., measured the effect of brefeldin A on uPAR-release. Brefeldin A inhibits protein secretion by preventing vesicle transport between the endoplasmatic reticulum and the Golgi [44]. uPAR release from ovarian cancer cells was not reduced in the presence of brefeldin $\mathrm{A}$, whereas release of the secretory protein TGF- $\beta$, was almost completely inhibited. This indicates that suPAR is derived from the cell surface and that Golgi-mediated secretion of an alternatively spliced receptor isoform is not responsible for the observed uPAR release. The group concluded that the majority of suPAR is thus generated by GPI-anchor cleavage catalyzed by GPI-PLD in their experiments.
Other proteases, including cathepsin G and PI-PLC, are known to also cleave the GPI-anchor and thus suPAR generated by GPI-anchor cleavage is not only regulated by one kind of proteases but more likely by a mixture of various proteases.

Cleavage of uPAR does not only occur at the GPIanchor portion of the protein, but also within the actual receptor. The linker region connecting $\mathrm{D}_{\mathrm{I}}$ and $\mathrm{D}_{\mathrm{II}-\mathrm{III}}$ can be cleaved by several different proteases including the uPAR ligand (uPA), plasmin, chymotrypsin, various metalloproteinases (MMPs) and elastases [3,18,29,41]. These studies are based on uPAR, but as suPAR shares the same overall structure these proteases are likely to cleave suPAR as well. An exception of this hypothesis is uPA-catalyzed cleavage which is limited to only membrane-bound UPAR, and is therefore not able to cleave soluble uPAR at physiological conditions [43]. The uPAR cleavage sites are illustrated in Fig. 5.

Several other proteases are known to cleave uP$\mathrm{AR}$ in vitro but whether these are able to cleave under physiological conditions in vivo is uncertain [76]. uPA is one of the most recognized proteases in cleaving membrane-bound UPAR at Arg83 as illustrated in Fig. $5[41,43]$. The fast uPA-catalyzed cleavage of uP$\mathrm{AR}$ at the cell surface requires receptor binding of uPA through its growth factor domain which concentrates the enzyme to clusters of uPAR [41]. Cleavage of uPAR in cultured MDA-MB-231 cells and Lewis lung carcinoma cells was found to be inhibited by anti-catalytic antibodies to either human or murine uPA, respectively, indicating that it is catalyzed by either UPA or plasmin generated by uPA. The amount of uPAR ${ }_{\text {II-III }}$ may therefore be directly related to the activity of the uPA 
Table 1

uPAR- and suPAR forms generated by cleavage in the linker region. The structural features of uPAR and suPAR are summarized and the localization and molecular mass measured for the different forms are provided for both glycosylated and non-glycosylated fragments (shown in parentheses)

\begin{tabular}{|c|c|c|c|c|}
\hline Fragments & Structure & $\begin{array}{l}\text { Physical } \\
\text { Characteristics }\end{array}$ & $\begin{array}{l}\text { Molecular } \\
\text { Mass kDa* }\end{array}$ & Localization \\
\hline $\mathrm{uPAR}_{4-111}$ & & $\begin{array}{l}\text { Full length } \\
+\mathrm{GPI} \text { anchor }\end{array}$ & $\begin{array}{l}\sim 55-60 \\
(35)^{[1][2]}\end{array}$ & $\begin{array}{l}\text { Membrane- } \\
\text { bound }\end{array}$ \\
\hline $\mathrm{uPAR}_{\mathrm{II-III}}$ & & $\begin{array}{l}\text { Cleaved } \\
+\mathrm{GPI} \text { anchor }\end{array}$ & $\begin{array}{l}\sim 45-50 \\
(27)^{[3]}\end{array}$ & $\begin{array}{l}\text { Membrane- } \\
\text { bound }\end{array}$ \\
\hline suPAR $_{1-I I I}$ & & $\begin{array}{l}\text { Full length } \\
\text { - GPI anchor }\end{array}$ & $\begin{array}{l}\sim 55-60 \\
(35)^{[4][5]}\end{array}$ & Soluble \\
\hline suPAR $_{11-11}$ & & $\begin{array}{l}\text { Cleaved } \\
\text { - GPI anchor }\end{array}$ & $\begin{array}{c}\sim 40-45 \\
(27)^{[6][7]}\end{array}$ & Soluble \\
\hline suPAR & & $\begin{array}{l}\text { Cleaved } \\
\text { - GPI anchor }\end{array}$ & $\sim 16(9)^{[8]}$ & Soluble \\
\hline GPI-ar & & region $\mathrm{D}_{1}$ : Doma & $\mathbf{D}_{\|}:$Domain 2 & $\mathbf{D}_{\text {III }}$ Domain 3 \\
\hline \multicolumn{5}{|c|}{$\begin{array}{l}\text { *The molecular mass is listed for glycosylated proteins. The molecular mass for non-glycosylated } \\
\text { proteins is shown in parentheses }{ }^{[1]} \text { Niel sen et al, } 1988 ;{ }^{\left[{ }^{2]}\right.} \text { Roldan et al., 1990; }{ }^{[3]} \text { Høyer-Hansen et } \\
\text { al., 1992; }{ }^{[4]} \text { Ploug et al, 1991; }{ }^{[5]} \text { Ploug et al, 1992a; }{ }^{[6]} \text { Wahl berg et al., 1998; }{ }^{[7]} \text { Høyer Hansen et al } \\
\text { 2001; }{ }^{[8]} \text { Behrendt et al,, 1991. }\end{array}$} \\
\hline
\end{tabular}

system and it is possible that the level of uPAR ${ }_{I I-I I I}$ in cancer tissue may prove to be a stronger prognostic parameter than the levels of either full-length uPAR or uPA [97]. Furthermore, uPA, once bound to UPAR, catalyzes the conversion of plasminogen into plasmin, the latter participating in turn to the activation of various matrix metalloproteinases (MMPs) [6]. One of these MMPs can be human macrophage elastase (MMP-12). It has been demonstrated that MMP-12 and other MMPs directly and efficiently cleave UPAR at the Thr86 located in the linker region [3]. Using an antibody raised against the human $\mathrm{UPAR}$ linker region, Andolfo et al., showed that this region of UPAR, which contains a specific chemotactic epitope, is exposed upon MMP cleavage [3]. MMP-12 is part of a group of elastases which generally is associated with leukocytes and is defined as enzymes that have the capacity to degrade insoluble elastin into soluble peptides [67]. Also cathepsin $G$ and elastase cleave uPAR within the linker-region, while in addition cathepsin $\mathrm{G}$, which has a chymotrypsin-like catalytic activity, is highly efficient in cleaving the $C$ terminus of $D_{\text {III }}[6,67]$.

The various UPAR- and suPAR forms generated by cleavage of the GPI-anchor and/or the linker region are summarized and illustrated in Table 1.

\section{2. $u P A R / u P A$ and suPAR in cell migration and adhesion}

Cell migration across the blood barrier and into tissues is an essential component in inflammation, immune response against infection, cancer invasiveness and tissue remodeling following injury. The migration process is tightly linked to adhesion and chemotaxis, as chemoattractant receptors direct oriented migratory signals and adhesion receptors modulate interactions of migrating cells with the adjacent cells and tissue. The uPAR/uPA system is directly involved in these mechanisms [10,21], which has been proven by the observation of profound impairment of inflammatory cell recruitment in UPA-/- mice. These mice succumb to infection by Cryptococcus neoformans due to deficient $\mathrm{T}$ lymphocyte and monocyte-macrophage recruitment [35]. Gene knockout mice lacking uPAR have shown reduced pulmonary neutrophil recruitment and increased mortality to infection with $S$. pneumoniae compared to wild-type mice [81]. May et al., demonstrated by studies in uPAR knockout mice, that adherence and migration of monocytes involves a functional interaction between uPAR and integrins [57]. In non- 
migrating cells, uPAR is distributed on the cell surface at focal contacts [27] but uPAR is able to move on the cell surface [61] and will localize into aggregates on the leading edge of migrating cells $[27,34,61,94]$ and is believed to regulate the activation state of integrins [47] by altering their adhesive properties as well as signaling capacity, which is supported by studies documenting uPAR-dependent changes in integrin-mediated adhesion to fibrinogen, collagen and vitronectin [108,109]. These findings suggest a role for UPAR in cell adhesion, migration and intercellular signaling. However, suPAR is believed to have inhibiting properties on UPARdependent adhesion, as it is soluble and therefore not able to direct integrin and vitronectin molecules to the focal contacts $[31,60]$.

Because of vitronectins implication in cell adhesion and cell morphology and the direct parallel between the extent of uPA binding to UPAR and increase in vitronectin binding [104], elucidation of the biological mechanism lying behind these observations could be valuable for further insights into tumor cell metastasis, ovulation, cell migration and tissue remodeling. Vitronectin is an extracellular plasma protein found in blood vessel walls, in the stroma of lymphatic tissue, lymph nodes and loose connective tissue of many organs [79] and has been implicated in several physiological and pathological processes including rheumatoid arthritis and angiogenesis and is found to be increased in arthrosclerosis and in several tumors [25, 32]. Waltz and Chapman, 1994 was the first to show that soluble (urea-purified) vitronectin is implicated in the uPA-dependent adhesion of cytokine-stimulated myeloid cells, and in a later study they provided evidence that UPAR is also a high-affinity receptor for the matrix-like form of vitronectin which can be regulated by concurrent uPA receptor binding [104,107].

UPAR is found in lipid rafts and, interestingly, the resulting suPAR $\mathrm{II}-\mathrm{III}_{\mathrm{I}}$ is found to be associated with the rafts even after cleavage. As the cleavage of the receptor is accelerated in these lipid rafts, it is hypothesized that this could result in rapid generation of a high local concentration of suPAR II-III. The cleavage is furthermore found to regulate the dimerization [18]. Lately, studies have primarily focused on the oligomerization of membrane-bound UPAR $[13,18]$ and recent findings have demonstrated that the biological activity of $\mathrm{UPAR}_{\mathrm{I}-\mathrm{III}}$ in cell adhesion and migration requires a direct interaction between UPAR and vitronectin [14, $26,38,54,55,104,107]$ and that vitronectin preferentially interacts with dimerized uPAR [18].

\section{SUPAR, SUPAR fragments and their functions}

\subsection{SUPAR $_{\mathrm{I}-\mathrm{III}}:$ Trash or treasure?}

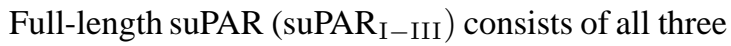
domains ( $\mathrm{D}_{\mathrm{I}}, \mathrm{D}_{\mathrm{II}}$, and $\left.\mathrm{D}_{\mathrm{III}}\right)$ of uPAR but lacks the GPIanchor. At first glance, it could be considered as "trash" shed from the cell surface, but as the receptor undergoes only a slight conformational change when shed through GPI-anchor cleavage, it could still represent a functional receptor. The presence of the uPA-binding $\mathrm{D}_{\mathrm{I}}$ domain of UPAR [8] suggests that suPAR ${ }_{\text {I-III }}$ should be able to compete with uPAR $\mathrm{I}_{-\mathrm{III}}$ for UPA. It has indeed been demonstrated that the soluble receptor retains its ability to specifically bind uPA [56]. The linker region connecting $\mathrm{D}_{\mathrm{I}}$ with $\mathrm{D}_{\mathrm{II}-\mathrm{III}}$ contains a uPA-cleavage site (see Fig. 5), but Høyer-Hansen et al., demonstrated that the soluble form, in contrast to the membrane-bound form, was not cleaved by uPA. This finding confirms the hypothesis that suPAR $\mathrm{R}_{\text {-III }}$ can act as uPA scavenger and that it might therefore have possible implications of inhibiting cancer-promoting actions i.e. the proteolysis involved in cancer cell metastasis.

Høyer-Hansen et al., demonstrated that $\mathrm{D}_{\mathrm{I}}$ is required for efficient binding of vitronectin $[40,42]$. The functional epitope on UPAR responsible for its interaction with vitronectin was identified by Gårdsvoll \& Ploug, by using a comprehensive alanine-scanning library of purified single-site uPAR mutants. The five residues identified as "hot spots" for vitronectin binding forms an epitope consisting of two loops connecting the central four stranded beta-sheet in uPAR D (Trp32, Arg58, and Ile63) as well as a region of the flexible linker-region connecting uPAR $\mathrm{D}_{\mathrm{I}}$ and $\mathrm{D}_{\mathrm{II}}$ (Arg91 and Tyr92) [36]. As suPAR $\mathrm{I-III}$ is a full-length receptor with all domains intact it should also be able to bind vitronectin; Sidenius et $a l$., have indeed demonstrated that suPAR binds vitronectin and furthermore, that this binding is dependent on uPA concentration [91]. The group suggested that the oligomeric uPA:suPAR complex identified by chromatography was a heterotrimeric complex composed of one ligand (uPA) molecule and two receptor (suPAR) molecules. This was based on the observation that suPAR:suPAR co-immunoprecipitated, but also on the fact that vitronectin-binding was found to occur most efficiently when a 1:2 molar ratio between concentrations of pro-uPA and suPAR was present. When uPA was in excess, it caused suPAR:suPAR to coprecipitate and it was furthermore demonstrated that high uPA concentration results in a strong and consis- 
tent inhibitory effect on vitronectin-binding to suPAR. The most likely mechanism for this was proposed to be a very rapid saturation of suPAR by excess UPA, thus preventing the subsequent association between heterodimeric pro-uPA:suPAR complexes and unoccupied suPAR [91]. These observations reveal a complicated picture of full-length suPAR's involvement in regulation of UPA/uPAR-actions: suPAR seems to be able to bind both uPA and vitronectin and hence affect the processes catalyzed by those molecules and their interaction with membrane-bound UPAR.

\section{2. sUPAR $_{\mathrm{II}-\mathrm{III}}-$ a cleaved receptor with an after life}

suPAR is an interesting receptor in the way that it keeps a molecular relevance even after being shed from the membrane where it is found to be involved in various cellular processes. It is even more intriguing how this receptor "survives" a further degradation in the linker region and stays intact as a two-domain protein circulating in the blood. As this cleaved and soluble receptor is not further degraded and hence is stable enough to be measured in various body fluids, it is tempting to conclude that this cleaved receptor does indeed exert an important function, although the exact molecular mechanisms are still not fully described. The structural difference between suPAR $\mathrm{II}_{\text {-III }}$ compared to suPAR $\mathrm{I}_{\mathrm{III}}$ is a loss of the uPA-binding domain $\mathrm{D}_{\mathrm{I}}$ by linker region cleavage. The loss of $\mathrm{D}_{\mathrm{I}}$ domain indicates that suPAR $\mathrm{II}-\mathrm{III}_{\mathrm{I}}$ is not acting as UPA-scavenger. Høyer-Hansen et al., demonstrated that $\mathrm{D}_{\mathrm{I}}$ is required, but not sufficient for efficient binding of vitronectin to uPAR $_{\text {II-III }}$ [42] which indicates that suPAR $_{\text {II-III }}$ is unable to bind vitronectin as well. Thus suPAR $\mathrm{II}$-III cannot compete with uPAR I-III $_{\text {for vitronectin nor } \mathrm{UPA}}$ and its involvement in regulation of such interactions thus seems limited.

However, the function of this cleaved receptor has been studied further and it has now been well documented that suPAR ${ }_{I I-I I I}$ is a chemotactic agent $[29,77$, $78,86]$ that has been identified in blood from prostate cancer patients [70], ovarian cystic fluids [103], ovarian cancer cells [110] and in urine from patients suffering from cancer $[60,93]$.

Chemotaxis is defined as movement of cells according to a chemotactic gradient. The chemotactic gradient can be sensed by the cells through the use of 7trans-membrane (7TM) receptors, which translate the extracellular signal into activation of an intracellular signaling pathway $[4,11]$. The chemotatic properties of suPAR were first discovered through its ability to stimulate LB6 cell migration. A chymotrypsin-cleaved purified mutant of suPAR (suPAR $\mathrm{II-III}$ ) was tested on untransfected parental murine LB6 cells and it was found to behave as a potent chemoattractant in a dose dependent manner [77]. The ability of suPAR II-III to stimulate chemotaxis was later confirmed in several other cells including LB6-19 [77], THP-1 [29,77], human monocytes [78] and CD34+ hematopoietic stem cells [86].

To further investigate the chemotactic properties of suPAR, Fazioli et al., have constructed truncat-

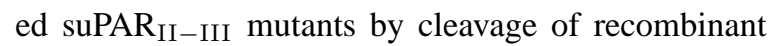
suPAR with chymotrypsin to identify the chemotactically active region. Only fragments containing the SRSRY sequence (residues 88-92) showed a chemotactic effect and this sequence promoted chemotactic properties both when present on the $\mathrm{C}$-terminus, as in suPAR $_{I}$, and when present in the N-terminus, as in

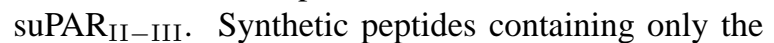
SRSRY-sequence were shown to exert the chemotactic property on several cell lines, which supports the conclusion that the SRSRY-sequence is essential and sufficient for chemotaxis [29,78,31]. A rapid release of the

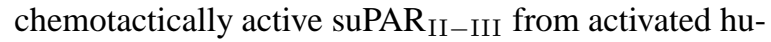
man neutrophils has been demonstrated recently [72]. The actual biological function of the molecule is still not clear but it is hypothesized that the production of this active form of suPAR by activated neutrophils in sites of acute inflammation contributes to the recruitment of monocytes to these sites during an inflammatory response [72].

suPAR $_{\text {II-III }}$ is so far believed to be generated by two routes: The first is through cleavage of the GPIanchor of membrane-bound UPAR $_{\text {I-III }}$, and subsequent cleavage of the soluble suPAR $\mathrm{I}_{\mathrm{III}}$ in the linker region (as illustrated in Fig. 6, reaction pathway 2). As discussed above, many proteases are known to cleave the linker-region connecting $\mathrm{D}_{\mathrm{I}}$ and $\mathrm{D}_{\mathrm{II}-\mathrm{III}}$, thus resulting in suPAR $\mathrm{II-III}_{\text {. However, suPAR }}$-III is lacking the GPI-anchor and can therefore not be cleaved by physiological relevant concentrations of uPA, due to conformational changes induced by cleavage of the GPI-anchor [43]. It can be hypothesized that gener-

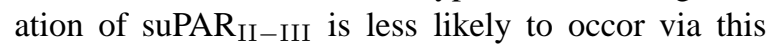
pathway, as the conformational change following GPIanchor cleavage may also affect other proteases known to cleave the linker region.

The second, and more likely, route by which cells can generate suPAR $\mathrm{R}_{\mathrm{II}-\mathrm{III}}$ in vivo is by cleavage of the linker region of the membrane-bound $\mathrm{UPAR}_{\mathrm{I}-\mathrm{III}}$ prior 


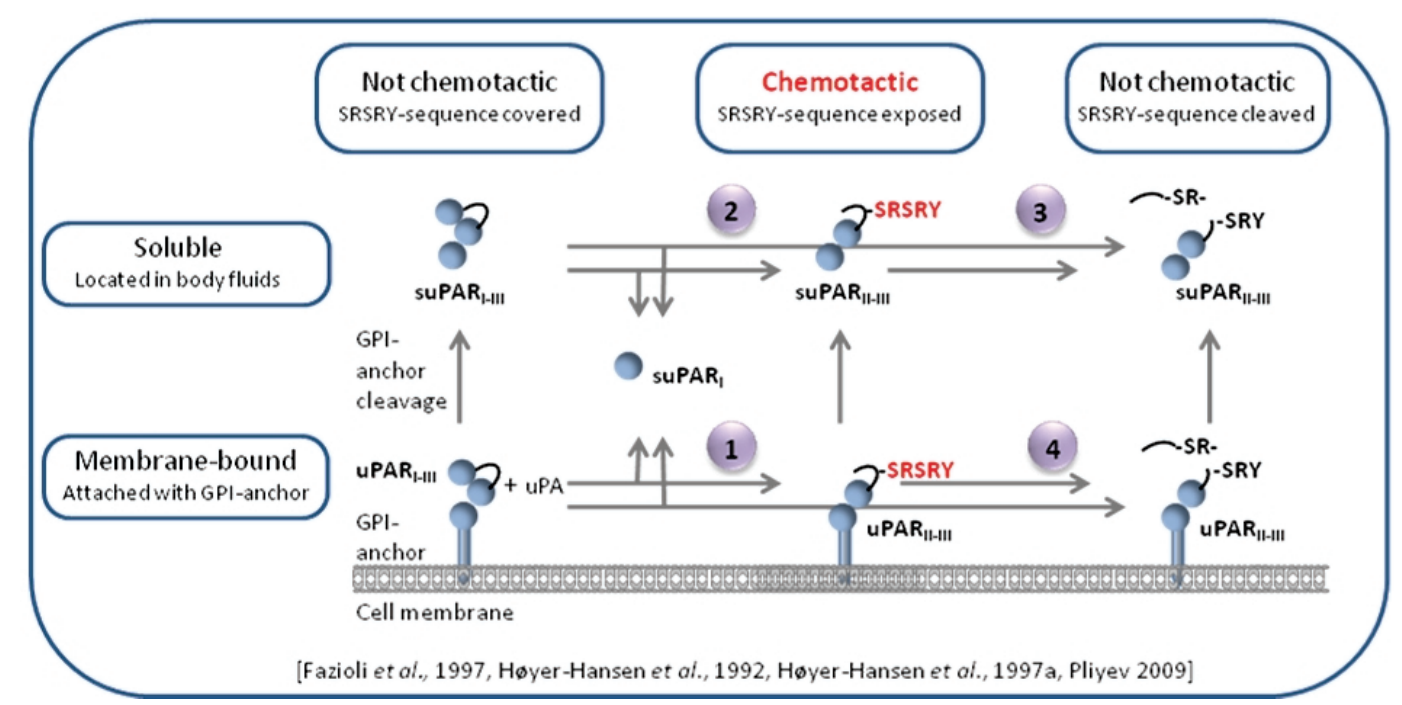

Fig. 6. Schematic representation of suPAR release and cleavage. The reaction pathways leading to generation of various uPAR- and suPAR-forms are illustrated. The top-horizontal line of molecules represents the three variants of suPAR that are soluble, while the bottom-horizontal line of receptors is the membrane-bound uPAR-variants. Only the cleaved uPAR/suPAR illustrated with intact SRSRY-sequence are believed to have chemotactic properties $[29,40,41,72]$.

to GPI-anchor cleavage. Cleavage of the linker region in uPAR $_{\mathrm{I}-\mathrm{III}}$ will not release the cleaved $\mathrm{UPAR}_{\mathrm{II}-\mathrm{III}}$ from the membrane as the GPI-anchor is intact, but will only liberate the $\mathrm{D}_{\mathrm{I}}$ of the receptor (as illustrated in Fig. 6, reaction pathways 1 and 4). Reaction pathway 1 symbolizes a cleavage inside the linker region, but outside the SRSRY-sequence, and therefore results in a chemotactic, membrane-bound uPAR-molecule, whereas reaction pathway 4 symbolizes cleavage within the SRSRY-sequence in the linker region and results in a non-chemotactic uPAR-molecule as illustrated in the figure [72]. Cleavage of suPAR $\mathrm{I}-\mathrm{III}_{\text {at Tyr87 re- }}$ sults in the active chemotactic suPAR $\mathrm{R}_{\mathrm{II}-\mathrm{III}}$ molecule, while cleavage at a second site, Arg89, will destroy the chemotactic activity, as it would cleave within the conserved region. This second site is one of two natural cleavage sites for uPA, as incubation with uPA results in a mixture of molecules with N-terminal amino acids Ala84 or Ser90 [41]. However, as suPAR is not susceptible to uPA cleavage, plasmin may be the primary protease regulating cleavage in the chemotactic SRSRYsequence of suPAR $\mathrm{I}_{\text {-III. }}$. Following cleavage of the linker-region, $\mathrm{uPAR}_{\mathrm{II}-\mathrm{III}}$ can be released by GPIanchor cleavage and hence become suPAR ${ }_{\text {II-III }}[6,29$, 78]. Again, this can result in a chemotactic suPAR II-III with intact SRSRY-sequence or it can result in a nonchemotactic suPAR ${ }_{\text {II-III }}$ as illustrated in Fig. 6 [29]. For both $\mathrm{uPAR}_{\mathrm{II}-\mathrm{III}}$ and suPAR $\mathrm{RI}_{\mathrm{III}}$, liberation of the $\mathrm{D}_{\mathrm{I}}$-domain prevents uPA binding and thereby plas- minogen activation, as $D_{\text {I }}$ is required for UPA to bind to its receptor. Furthermore, cleavage in the linker region also abolishes uPAR-dependent cell adhesion, since vitronectin does not bind $\mathrm{uPAR}_{\text {II-III }}[41,88]$. As suPAR $\mathrm{RI}_{\mathrm{III}}$ in general shares the same structural features as uPAR $\mathrm{R}_{\mathrm{II}-\mathrm{III}}$; i.e. lacks the $\mathrm{D}_{\mathrm{I}}$-domain, vitronectin most likely does not bind to suPAR $\mathrm{II-III.} \mathrm{Thus}$ suPAR $_{I I-I I I}$ may, as $\mathrm{uPAR}_{\mathrm{II}-\mathrm{III}}$, be a negative regulator of the UPAR-dependent cell adhesion.

Pliyev demonstrated that neutrophil-derived suPAR was shown to increase rapidly during neutrophilactivation and that the suPAR found, was primarily the cleaved suPAR ${ }_{\text {II-III }}$ [72]. It can be hypothesized that the majority of this suPAR ${ }_{\text {II-III }}$ pool is directly shed from neutrophil cell membranes, rather than circulating suPAR I-III $_{\text {is slowly cleaved by proteases }}$ as a response to the activation (reaction pathway 2). This is in agreement with observations made by Pliyev: That the suPAR $\mathrm{II}_{\mathrm{III}}$-release could not be explained by the release of intracellular stores of suPAR $\mathrm{RI}_{\mathrm{IIII}}$ upon neutrophil degranulation or shedding of UPAR containing vesicles. These results indicate that circulating suPAR $\mathrm{RI}_{\text {-III }}$ primarily results from GPI-anchor cleavage of membrane bound UPAR ${ }_{\text {II-III }}$ and not from cleavage of circulating suPAR $\mathrm{I}_{\mathrm{IIII}}$. However it was observed, that suPAR release from resting and activated human neutrophils was metalloproteinase- and PI-PLD-independent. Thus, the enzyme(s) that is responsible for suPAR release from human neutrophils remain(s) to be identified [72]. 


\subsection{Signaling significance of suPAR $\mathrm{II-III}$}

The membrane attachment of UPAR via a GPI anchor i.e. the lack of an intracytoplasmic region capable of connecting with the cytoplasmic signal transducers, provoked several groups to focus on identifying a transmembrane adaptor that could mediate the activation of intracellular transducers [29,78]. Fazioli et al., hypothesized that the SRSRY sequence must interact with a cell surface protein which can signal through a heteromeric $\mathrm{G}$ protein and the group showed that a synthetic UPAR chemotactic epitope activates p56/p59 hck and that both chemotaxis and activation of p56/p59 hck are pertussis toxin (PTX) sensitive, implying a connection between $\mathrm{G}$ proteins and intracellular protein tyrosine kinases. This result confirmed the $\mathrm{G}$ protein dependence of uPAR/suPAR chemotaxis and suggests that the activation of tyrosine kinases is a downstream step from the heterotrimeric $\mathrm{G}_{i}$ protein [29]. This was confirmed with results indicating that $\mathrm{p} 56 / \mathrm{p} 59^{\text {hck }}$ is a probable downstream effector of uPAR-mediated signal transduction and that $\mathrm{p} 56 / \mathrm{p} 59^{\mathrm{hck}}$ is a common mediator of both chemotactic and adhesive responses [15,77]. Later, Resnati et al., found that the 7TM receptor FPR-like receptor 1 (FPRL1) is necessary and sufficient to mediate the chemotactic activity of suPAR II-III. Their work identified the suPAR $\mathrm{II}-\mathrm{III}_{\text {fragment as an endogenous }}$ ligand for FPRL1 and demonstrated that the chemotactic region SRSRY is required for the interaction. Especially the amino acid Tyr92 in the SRSRY sequence is essential for the interaction between FPRL1 and suPAR $_{\text {II-III }}$ [78]. FPRL1 is a low affinity variant of the fMLF receptor which belongs to the Gi protein-coupled receptor super family (GPCR), and which also includes chemokine receptors. The receptor is expressed by monocytes, lymphocytes and neutrophils and up regulated by various cytokines and growth factors [49]. Activation of the FPRL1 leads to desensitization to its ligand formyl-methyonyl-leucyl-proline (fMLP) and inhibition of chemokine-induced monocyte chemotaxis to MCP-1 [31,78]. Cells with undetectable FPRL1 or uPAR do not respond to the suPAR $\mathrm{RI}_{\text {III }}$ but transfection with FPRL1 into uPAR-deficient cells restores their re-

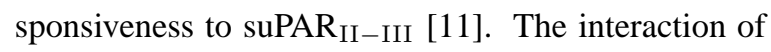
suPAR with FPRL1 was later confirmed by Pliyev, who showed that TNF- $\alpha$-primed and IL-8-stimulated neutrophils release the chemotactically active suPAR ${ }_{\text {II-III }}$ that utilizes FPRL1 as a functional receptor mediating its effect [72].

It has been suggested that the determining factor for receptor cleavage is not the actual uPA concentration, but rather the ligand/receptor ratio [41]. Blocking the release of UPAR with inactivated uPA did not have a pronounced effect on uPA-catalyzed cleavage suggesting that the activity of receptor-bound UPA in this case is not primarily directed against the same suPAR molecule on which it is bound. However, the same study determined that the required ligand/receptor ratio is 5:1 for efficient cleavage in solution under their experimental conditions and a ligand/receptor ratio less than 1:1 was required for efficient cleavage of UPAR on the cell surface [41].

In conclusion, there seems to be very strong evidence that suPAR $\mathrm{RI}_{\text {IIII }}$ is mediating a chemotactic effect on immunologically active cells, but the regulation of the receptor cleavage and hence generation of the chemotactic suPAR-fragments is still not fully understood. Clearly, suPAR $\mathrm{II}_{\text {-III }}$ is implicated in the inflammatory response as will be discussed below for several diseases, but whether it is promoting the immune response or merely just a result of an increased activation level of the immune system is still not clear.

\section{4. $s u P A R_{\mathrm{I}}$ : a left-over component?}

suPAR $\mathrm{I}_{\mathrm{I}}$ constitutes the $16 \mathrm{kDa}$ ligand-binding domain $\left(\mathrm{D}_{\mathrm{I}}\right)$ of the UPA receptor. This $\mathrm{NH}_{2}$-terminal domain of the suPAR molecule is liberated from fulllength suPAR $\mathrm{I}_{\text {-III }}$ by cleavage of the linker region with a protease, which abolishes ligand binding of uPAR and thereby plasminogen activation as $\mathrm{D}_{\mathrm{I}}$ is required for uPA to bind to its receptor $[41,88]$. $D_{\text {I }}$ may seem like an important fragment of suPAR as this domain is required for binding of $\mathrm{UPA}$ and vitronectin. The experimental finding that the $\mathrm{D}_{\mathrm{I}}$ fragment behaves as a distinct, structural domain is in accordance with the cDNA sequence analysis of internal homology in $u-$ PAR, revealing $D_{I}$ as more distantly related to $D_{\text {II }}$ and $\mathrm{D}_{\text {III }}$ (see Fig. 3), however, studies have indicated that the isolated $\mathrm{D}_{\mathrm{I}}$ has a much lower uPA affinity than the intact UPAR [75]. Furthermore, $\mathrm{D}_{\mathrm{III}}$, or the integrity of the $\mathrm{D}_{\mathrm{II}}-\mathrm{D}_{\mathrm{III}}$ part of suPAR, is required for strong ligand binding [9]. This indicates that $\operatorname{suPAR}_{\mathrm{I}}$ is rather ineffective as an UPA-scavenger.

High amounts of urine-suPAR $\mathrm{I}_{\mathrm{I}}$ are found in urine samples from acute myeloid leukemia patients with a high number of tumor cells in the circulation. Only one of eight patients with a low number of tumor cells in the circulation had, at diagnosis, detectable amounts of suPAR $_{I}$ in the urine [60]. Whereas full-length uPAR and suPAR is found in cell lysates, in plasma, in bonemarrow plasma, and in urine, different fragments of 
uPAR show different distributions: suPAR ${ }_{I I-I I I}$ is, like

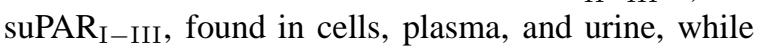
suPAR $\mathrm{I}_{\mathrm{I}}$ is found only in urine [60]. The presence of $\mathrm{D}_{\mathrm{II}}-\mathrm{D}_{\mathrm{III}}$ in cells and previous demonstration that cleavage does not occur in urine [90] made Mustjoki et al., suggest that $\mathrm{D}_{\mathrm{I}}$ is produced by cleavage of uPAR in the cells and that the clearance time of $\mathrm{D}_{\mathrm{I}}$ must therefore be very short because they had have never detected it in cell lysates or in plasmas [60]. Beaufort et al., documented a fast proteolytic degradation of the $\mathrm{D}_{\mathrm{I}}$ fragment, which disapear within $30 \mathrm{~min}$. after liberation from UPAR activated polymorphonuclear neutrophils.

\section{SUPAR and diseases}

suPAR levels are thought to reflect the state of immune activation of the individual. This is substantiated by findings of increased suPAR levels in individuals suffering from viral, bacterial or parasitical infections as well as autoimmune diseases and cancer. Interestingly, in all of these conditions the higher the concentration of suPAR, the worse the prognosis of the disease $[5,28,69,89,92,96,101,111,113]$.

At first, uPAR was thought to be disease-specific, given uPAR's up-regulation on cancer cells, involvement in extracellular proteolysis and the prognostic value of suPAR in predicting the severity of cancer and an unfavorable clinical outcome. As antagonists of uPA or UPAR were shown to prevent growth, invasiveness and metastasis of tumors [58] development of antagonists to the uPA-uPAR system for human cancer therapy commenced and several product candidates are in pre-clinical and early clinical development. HIV infection was linked to the UPA-uPAR system by findings including the enhanced expression of uPAR on the cell surface of monocytes and lymphocytes in vitro [99]. Based on these observations Sidenius et al., first investigated the correlation between serum suPAR levels and HIV-1 disease prognosis in 2000 and found the by now well documented increase of suPAR levels in HIV-1 infected individuals and its power as a prognostic marker, with strength similar to, and independent of, CD4 counts and viral load. Hereafter the picture broadened to reveal that suPAR's predictive power is unspecific to the respective disease, as it reflects the overall systemic inflammation and immune activation common to many life-threatening diseases. In agreement with the hypothesis of immune activation/inflammation, a high level of suPAR was associated with worse prognosis in several diseases, including tuberculosis [24] and malar- ia [65]. Latest, suPAR was shown to be a potential standardized assessment tool in critical care [45]. This is of clear importance as economic as well as patient survival considerations are calling for better tools to evaluate the state of patients with community-acquired infections, most notably with the systemic inflammatory response syndrome (SIRS).

\subsection{SUPAR and SIRS}

SIRS patients represent a large group of patients reporting to Emergency Departments [102] and a wealth of literature suggests that accurate and timely identification of high-risk patients is needed to ensure the optimal use of health care resources (see Kofoed 2008 and reference therein).

Early aggressive treatment for identified high-risk SIRS patients is thought to ultimately improve survival, and distinction of those from others requires standardized and fast assessment tools: Physicians rely largely on experience and intuition to triage SIRS patients, which is an approach that is not easily reproduced or taught to others, as well as on assessments with long time-lags, as is often the case with microbial cultures.

Kofoed et al., investigated a range of new and established biomarkers, marker combinations and assessment tools in a prospectively collected cohort of patients with systemic inflammatory response syndrome (SIRS) that were admitted to an emergency department and a department of infectious diseases. The area under the receiver operating characteristic (ROC) curve for the prediction of 30-and 180-day mortality was used to compare the performance of the markers and the models: suPAR, especially when combined with age, outperformed other markers, and even yielded a slightly better result than the comprehensive and elaborate predictive models of simplified acute physiology score II (SAPS II) and sequential organ failure assessment (SOFA).

\section{2. $S U P A R$ and $T B$}

TB patients represent a great challenge both with regard to diagnosis of active or latent infection and to monitoring of treatment efficacy. As in SIRS patients, suPAR is elevated by active TB disease, suPAR levels at time of TB treatment initiation is prognostic for survival during the 8-month treatment period, and in those who successfully complete the treatment, suPAR levels decrease to the level of non-infected individuals [28]. 
Siawaya and coworkers recently investigated a number of markers, including suPAR, for their ability to predict TB treatment efficacy. The study included 20 culture positive TB patients who were followed with blood samples during the treatment and 13 healthy community controls. The group found that patients with active TB had significantly higher suPAR levels at time of treatment initiation compared to the community controls. After one week of TB treatment, a significant decrease in suPAR was observed, and at the end of treatment the TB patient's suPAR level had decreased to the level of the controls.

Thus, suPAR seems a very promising biomarker in TB and suPAR as a marker of TB treatment efficacy is under investigation in a large EU FP6 funded study and the data will be published in 2009 (Rabna et al., submitted).

\subsection{SUPAR and HIV}

Similar benefits of the prognostic potential have been documented extensively for use of suPAR in HIV patients. suPAR was shown to be a strong predictor of immunologic failure and mortality in HAART naive patients with HIV-1 infection with a prognostic strength similar to that of CD4+ T-cell count and HIV-1 viral load $[66,89]$.

Schneider et al., highlighted the combined prognostic value of suPAR and CD4 by showing that both markers added clinical value on the risk of mortality in nonART treated HIV-1 patients. Within a two-year followup period, patients with a low CD4 count (defined as below 200) and high suPAR levels (defined as above $6 \mathrm{ng} / \mathrm{ml}$ ) had high two-year mortality while those with low CD4 and low suPAR levels had low two year mortality [85]. A cut-off limit for suPAR at maximum 6 $\mathrm{ng} / \mathrm{mL}$ was suggested for initiation of ART, in particular in cases of CD4 between 350 and 200 cells per ul, which needs to be confirmed in larger patient populations; also the dynamics of suPAR in relation to HIV progression needs to be further addressed. For clinical practice the fact that plasma suPAR levels are not affected by UPAR promoter polymorphisms [85] increase the potential value of suPAR as a biomarker for HIV progression and treatment initiation. Also in patients receiving HAART suPAR was shown to decrease with effective therapy suggesting its potential as a treatment efficacy marker [64] with potential clinical benefits.

Overall, the above described studies argue for a place of suPAR amongst routine HIV patient assessment: So far dominated by HIV RNA viral load and CD4 cell counts, the former of which requires expensive, high technology laboratory facilities, suPAR is proposed as a robust and reliable prognostic marker that can also be used in resource-limited settings.

The implications of suPAR as a clinical HIV management tool were recently extended to prognostic information of the metabolic status of patients undergoing HAART [3], as HIV-infected patients receiving HAART have an increased risk of various metabolic disorders, which may involve low-grade inflammation and other immunological perturbations.

Andersen et al., found that plasma suPAR correlate with important features of dysmetabolism, as strong correlations between plasma suPAR and the number of white blood cells, TNF-a, fat distribution, insulin sensitivity, and measures of lipidemia could be demonstrated. In addition, the presented data suggest that plasma suPAR is a stronger predictor of dysmetabolism than TNF-a and IL-6 as shown in multiple regression analyses.

A follow-up study [3] extends the correlation to an association between suPAR and glucose tolerance, which is a composite measure of insulin sensitivity, insulin secretion, proinsulin secretion and circulating fatty acids during an oral glucose challenge of HIV infected patients on stable HAART. Taken together these findings could link immunologic, infectious and metabolic characteristics of HIV patients receiving HAART and suggest suPAR as a potential marker of dysmetabolism in HIV patients on stable HAART.

\subsection{A good clinical marker}

suPAR's high stability in plasma samples make it a good candidate as a potential clinical marker: For example, suPAR levels in healthy individuals are known to be stable throughout the day [93] circadian changes in plasma concentration of suPAR in HIV-infected patients on stable HAART are shown to be very limited (see above), even repeated freeze-thaw procedures of plasma samples do not affect the suPAR concentrations [80]. Thus, suPAR measurements based on a biological fluid derived from a subject will be valid, independent of whether the subject is fasting or not, and largely independent of the sampling schedule.

\section{5. suPAR - a marker for low-grade inflammation?}

The work on suPAR's implication in HIV progression described above as well as the strong positive correlation between suPAR and TNF-a [3] and the corre- 
lation to C-reactive protein [96], which also predicts survival rates in HIV-1 infected individuals [48] lead to the hypothesis that suPAR levels indicate a heightened inflammatory state and thus link suPAR to the basic inflammatory response of the immune system.

Inflammation is occurring in the diseased person (infection, trauma, autoimmune disease) and suPAR seems a good marker for the level of the inflammation and hence provides a snapshot on the status of the immune system's battle against the pathogen.

However, in recent years the term low-grade inflammation is becoming commonly used. Low-grade inflammation, in contrast to inflammation, describes the immune state of a healthy individual (without disease). The current gold marker of low-grade inflammation is hsCRP, a sensitive assay for measurement of low levels of the acute phase protein C-reactive protein. Several studies have shown that slightly elevated hsCRP (not the high levels observed in infected individuals) is associated with increased risk of developing cardiovascular disease. Compared to CRP, suPAR is a stable protein in vivo, reflected in a less than 2-fold up regulation in individuals injected with LPS and in limited circadian fluctuation [3] indicating it may be a more stable marker of the immune state. Indeed, we have recently found that suPAR is a good marker of low-grade inflammation and predicts disease and mortality in the general population (Eugen-Olsen et al., submitted).

The documented involvement of suPAR in infectious diseases and pathological conditions makes suPAR a promising clinical marker. The strong prognostic value found across diseases may reflect a stronger linkage to immune activation compared to traditional markers of inflammation such as hsCRP, TNF-a and IL-6.

Several studies have documented the central role and involvement of suPAR in inflammatory responses and pathological conditions. The intriguing question is whether suPAR is promoting the pro-inflammatory immune response or whether this receptor and receptorfragments are merely a result of an increased activation level of the immune system. It will be interesting to see whether inhibition or removal of suPAR and suPAR fragments can reduce inflammation and disease progression.

In conclusion, suPAR and suPAR fragments reflect the activation state of the immune system and are involved in several immune regulating mechanisms. The prognostic value of suPAR levels across diseases position suPAR as a new promising inflammatory biomarker.

\section{Acknowledgements}

Thanks to Cand. Scient Fatma Al-Abaiji for her valuable comments. A special acknowledgement is going to Cand. Scient Anne Langkilde. We are very greatfull for her excellent feed-back and input for this review and for her consistent effort to contribute to this work.

\section{Competing interests}

$\mathrm{BM}$ is former CEO in ViroGates. ViroGates IP includes patents on using suPAR for diagnostic and prognostic purposes. MT is in employment at ViroGates and JEO is founder of, and shareholder in, ViroGates.

\section{References}

[1] H. Allgayer, H. Wang, G.E. Gallick, A. Crabtree, A. Mazar, T. Jones, A.J. Kraker and D.D. Boyd, J BiolChem 274 (1999), $18428-18437$.

[2] A. Andolfo, W.R. English, M. Resnati, G. Murphy, F. Blasi and N. Sidenius, Thromb Haemost 88 (2002), 298-306.

[3] O. Andersen, J. Eugen-Olsen, K. Kofoed, J. Iversen and S.B. Haugaard, Journal of Medical Virologi 80 (2008), 209-216.

[4] A. Bagorda and C.A. Parent, Journal of Cell Science 121 (2008), 2621-2624.

[5] R. Balabanov, D. Lisak, T. Beaumont, R.P. Lisak and P. Dore-Duffy, Clin Diagn Lab Immunol 8 (2001), 1196-1203.

[6] N. Beaufort, D. Leduc, J.C. Rousselle, V. Magdolen, T. Luther, A. Namane, M. Chignard and D. Pidard, The Journal of Immunology 172 (2004), 540-549.

[7] N. Behrendt, E. Rønne, M. Ploug, T. Petri, D. Løber, L.S. Nielsen, W.D. Schleuning, F. Blasi, E. Appella and K. Dan $\varnothing$, The Journal of Biological Chemistry 265 (1990), 6453-6460.

[8] N. Behrendt, M. Ploug, L. Patthy, G. Houen, F. Blasi and K. Danø, J Biol Chem 266 (1991), 7842-7847.

[9] N. Behrendt, E. Rønne and K. Dan $\varnothing$, J Biol Chem 271 (1996), 22885-22894.

[10] F. Blasi, Immunol Today 18 (1997), 415-417.

[11] F. Blasi and P. Carmeliet, Nat Rev Mol Cell Biol 3 (2002), 932-943.

[12] A. Børglum, A. Byskov, P. Ragno, A.L. Roldan, P. Tripputi, G. Cassani, K. Danø, F. Blasi, L. Bolund and T.A. Kruse, Am J Hum Genet 50 (1992), 492-497.

[13] V.R. Caiolfa, M. Zamai, G. Malengo, A. Andolfo, C.D. Madsen, J. Sutin, M.A. Digman, E. Gratton, F. Blasi and N. Sidenius, The Journal of Cell Biology 179 (2007), 1067-1082.

[14] P. Chaurasia, J.A. Aguirre-Ghiso, O.D. Liang, H. Gardsvoll, M. Ploug and L. Ossowski, (2006).

[15] F. Chiaradonna, L. Fontana, C. Lavarone, M.V. Carriero, G. Scholz, M.V. Barona and M.P. Stroppelli, The EMBO Journal 18 (1999), 3013-3023.

[16] J.R. Casey, J.G. Petranka, J. Kottra, D.E. Fleenor and W.f. Rosse, Blood 84 (1994), 1151-1156.

[17] B. Casslen, J. Nordengren, B. Gustavsson, M. Nilbert and L.R. Lund, J Clin Endocrinol Metab 80 (1995), 2776-2784. 
[18] O. Cunningham, A. Andolfo, M.L. Santovito, L. Luzzolino, F. Blasi and N. Sidenius, The EMBO Journal 22 (2003), 5994-6003.

[19] J. Dang, Y. Wang and W.F. Doe, FEBS Lett 359 (1995), $147-150$.

[20] J. Dang, D. Boyd, H. Wang, H. Allgayer, W.F. Doe and Y. Wang, Eur J Biochem 264 (1999), 92-99.

[21] K. Dan $\varnothing$, N. Behrendt, N. Brünner, V. Elis, M. Ploug and C. Pyke, Fibrinolysis 8 (1994), Suppl. 1, 189-203.

[22] C.E. De Bock and Y. Wang, Medicinal Research Reviews 24 (2004), 13-39.

[23] H. De Witte, F. Sweep, N. Brünner, J. Heuvel, L. Beex, N. Grebenschikov and T. Benraad, Int J Cancer 77 (1998), 236-242.

[24] J.F. Djoba Siawaya, M. Ruhwald, J. Eugen-Olsen and G. Walzl, Int J Infect Dis 11(4) (2007), 289-299.

[25] H. Ekmekçi, H. Sonmez, O.B. Ekmekçi, Z. Ozturk, N. Domanic and E. Kokoglu, Journal of Thrombosis and Thrombolysis 14 (2002), 221-225.

[26] C. Elia, E. Cassol, N. Sidenius, F. Blasi, A. Castagna, G. Poli and M. Alfano, Journal of Leukocyte Biology 82 (2007), 1212-1220.

[27] A. Estreicher, J. Miihlhauser, J.L. Carpentier, L. Orci and J.D. Vassalli, The Journal of Cell Biology 111 (1990), 783-792.

[28] J. Eugen-Olsen, P. Gustafson, N. Sidenius, T.K. Fischer, J. Parner, P. Aaby, V.F. Gomes and I. Lisse, Int J Tuberc Lung Dis 6 (2002), 686-692.

[29] F. Fazioli, M. Resnati, N. Sidenius, Y. Higashimoto, E. Appella and F. Blasi, EMBO J 16 (1997), 7279-7286.

[30] S. Florquin, J. Van Den Berg, N. Claessen, S.M. Opal, J.J. Weening and T. Van Der Poll, Kidney International 59 (2001), 2054-2061.

[31] F. Furlan, S. Orlando, C. Laudanna, M. Resnati, V. Basso, F. Blasi and A. Mondino, Journal of Cell Science 117 (2004), 2909-2916.

[32] C.L. Gladson and D.A. Cheresh, J Clin Invest 88 (1991), 1924-1932.

[33] J. Grøndahl-Hansen, L.R. Lund, E. Ralfkiaer, V. Ottevanger and K. Danø, J Invest Dermatol 90 (1988), 790-795.

[34] M.R. Gyetko, R. Todd III, C. Wilkinson and R. Sitrin, J Clin Invest 93 (1994), 1380.

[35] M.R. Gyetko, G.H. Chen, R.A. McDonald, R. Goodman, G.B. Huffnagle, C.C. Wilkinson, J.A. Fuller and G.B. Toews, J Clin Invest 97 (1996), 1818-1826.

[36] H. Gårdavoll and M. Ploug, The Journal of Biological Chemistry 282 (2007), 13561-13572.

[37] S. Hapke, M. Gawaz, K. Dehne, J. Kohler, J.F. Marshall, H. Graeff, M. Schmitt, U. Reuning and E. Lengyel, Mol Cell Biol 21 (2001), 2118-2132.

[38] T. Hillig, L.H. Engelholm, S. Ingvarsen, D.H. Madsen, H. Grdsvoll, J.K. Larsen, M. Ploug, K. Dan $\varnothing$, L. Kjøller and N. Behrendt, The Journal of Biological Chemistry 283 (2008), 15217-15223.

[39] Q. Huai, A.P. Mazar, A. Kuo, G.C. Parry, D.E. Shaw, J. Callahan, Y. Li, C. Yuan, C. Bian, L. Chen, B. Furie, B.C. Furie, D.B. Cines and M. Huang, Science 311 (2006), 656659.

[40] G. Høyer-Hansen, E. Rønne, H. Solberg, N. Behrendt, M. Ploug, L.R. Lund, V. Ellis and K. Danø, The Journal of Biological Chemistry 267 (1992), 18224-18229.

[41] G. Høyer-Hansen, M. Ploug, N. Behrendt, E. Rønne and K. Dan $\varnothing$, Eur J Biochem 243 (1997a), 21-26.

[42] G. Høyer-Hansen, N. Behrendt, M. Plough, K. Danø and K.T. Preissner, FEBS Letters 420 (1997b), 79-85.
[43] G. Høyer-Hansen, U. Pessara, A. Holm, J. Pass, U. Weidle, K. Dan $\varnothing$ and N. Behrendt, Biochem J 358 (2001), 673-679.

[44] R.D. Klausner, J.G. Donaldson and J. Lippincott-Schwartz, J Cell Biol 116 (1992), 1071-1080.

[45] K. Kofoed, U.V. Schneider, T. Scheel, O. Andersen and J. Eugen-Olsen, Clinical Chemistry 52 (2006), 1284-1293.

[46] K. Kofoed, J. Eugen-Olsen, J. Petersen, K. Larsen and O. Andersen, Eur J Clin Microbiol Infect Dis 27 (2008), 375385.

[47] M.C. Kugler, Y. Wei and H.A. Chapman, Curr Pharm Des 9 (2003), 1565-1574.

[48] B. Lau, A.R. Sharrett, L.A. Kingsley, W. Post, F.J. Palella, B. Visscher and S.J. Gange, Arch Intern Med 166 (2006), 64-70.

[49] Y. Le, B. Li, W. Gong, W. Shen, J. Hu, N.M. Dunlop, J.J. Oppenheim and J.M. Wang, Immunol Rev 177 (2000), 185194.

[50] E. Lengyel, H. Wang, E. Stepp, J. Juarez, Y. Wang, W. Doe, C.M. Pfarr and D. Boyd, J Biol Chem 271 (1996), 2317623184.

[51] K. List, G. Høyer-Hansen, E. Rønne, K. Danø and N. Behrendt, J Immonol Methods 222 (1999), 125-133.

[52] P. Llinas, M.H. Le Du, H. Grdsvoll, K. Danø, M. Ploug, B. Gilquin, E.A. Stura and A. Méndez, The EMBO Journal 24 (2005), 1655-1663.

[53] L.R. Lund, V. Ellis, E. Rønne, C. Pyke and K. Danø, Biochem J 310 (1995), 345-352.

[54] C.D. Madsen, G.M.S. Ferraris, A. Andolfo, O. Cunningham and N. Sidenius, The Journal of Cell Biology 177 (2007), 927-939.

[55] C.D. Madsen and N. Sidenius, European Journal of Cell Biology 87 (2008), 617-629.

[56] M.T. Masucci, N. Pedersen and F. Blasi, The Journal of Biological Chemistry 266 (1991), 8655-8658.

[57] A.E. May, S.M. Kanse, L.R. Lund, R.H. Gisler, B.A. Imhof and K.T. Preissner, J Exp Med 188 (1998), 1029-1037.

[58] H.Y. Min, L.V. Doyle, C.R. Vitt, C.L. Zandonella, J.R. Stratton-Thomas, M.A. Shuman and S. Rosenberg, Cancer Research 56 (1996), 2428-2433.

[59] H. Miyake, I. Hara, K. Yamanaka, K. Gohji, S. Arakawa and S. Kamidono, Prostate 39 (1999), 123-129.

[60] S. Mustjoki, N. Sidenius, C.F.M. Sier, F. Blasi, E. Elonen, R. Alitalo and A. Vaheri, Cancer Research 60 (2000), 71267132.

[61] H.T. Myohanen, R.W. Stephens, K. Hedman, H. Tapiovaara, E. Rønne, G. Høyer-Hansen, K. Danø and A. Vaheri, J Histochem Cytochem 41 (1993), 1291-1301.

[62] L.S. Nielsen, G.M. Kellerman, N. Behrendt, R. Picone, K. Dan $\varnothing$ and F. Blasi, Journal of Biological Chemistry 263 (1988), 2358-2363.

[63] H. Noda-Heiny, A. Daugherty and B.E. Sobel, Arterioscler Thromb Vasc Biol 15 (1995), 37-43.

[64] S.R. Ostrowski, T.L. Katzenstein, T. Piironen, J. Gerstoft, B.K. Pedersen and H. Ullum, Acquir Immune Defic Syndr 35 (2004), 337-342.

[65] S.R. Ostrowski, H. Ullum, B.Q. Goka, G. Høyer-Hansen, G. Obeng-Adjei, B.K. Pedersen, B.D. Akanmori and J.A.L. Kurtzhals, The Journal of Infectious Diseases 191 (2005a), 1331-1341.

[66] S.R. Ostrowski, T. Piironen, G. Hoyer-Hansen, J. Gerstoft, B.K. Pedersen and H. Ullum, J Acquir Immune Defic Syndr 39 (2005b), 23-31.

[67] C.A. Owen and E.J. Campbell, Journal of Leukocyte Biology 65 (1999), 137-150. 
[68] H. Pappot, G. Høyer-Hansen, E. Rønne, H. Hoi-Hansen, N. Brünner, K. Danø and J. Grøndahl-Hansen, Eur J Cancer 33 (1997), 867-872.

[69] M. Perch, P.E. Kofoed, T.K. Fischer, F. Có, L. Rombo, P. Aaby and J. Eugen-Olsen, Parasite Immunol 26 (2004), 207211.

[70] T. Piironen, B. Larsen, J. Pass, K. List, H. Grdsvoll, M. Ploug, K. Dan $\varnothing$ and G. Høyer-Hansen, Clin Chem 50 (2004), 2059-2068

[71] T. Piironen, A. Haese, H. Huland, T. Steuber, I.J. Christensen, N. Brünner, K. Danø, G. Høyer-Hansen and H. Lilja, Clin Chem 52 (2006), 838-844.

[72] B.K. Pliyev, Mol Cell Biochem 321 (2009), 111-122.

[73] M. Ploug, E. Rønne, N. Behrendt, A.L. Jemsen, F. Blasi and K. Danø, The Journal of Biological Chemistry 266 (1991), 1926-1933.

[74] M. Ploug, J. Eriksen, T. Plesner, N.E. Hansen and K. Dan $\varnothing$ Eur J Biochem 208 (1992), 397-404.

[75] M. Ploug, V. Ellis and K. Danø, Biochemistry 33 (1994), 8991-8997.

[76] M.G. Rasch, I.K. Lund, C.E. Almasi and G. Høyer-Hansen, Frontiers in Bioscience 13 (2008), 6752-6762.

[77] M. Resnati, M. Guttinger, S. Valcamonica, N. Sidenius, F. Blasi and F. Fazioli, EMBO J 15 (1996), 1572-1582.

[78] M. Resnati, I. Pallavicini, J.M. Wang, J. Oppenheim, C.N. Serhan, M. Romano and F. Blasi, PNAS 99 (2002), 13591364.

[79] J.T. Reilly and J.R. Nash, J Clin Pathol 41 (1988), 12691272.

[80] R. Riisbro, I.J. Christensen, C. Hogdall, N. Brunner and E. Hogdall, Int J Biol Markers 16 (2001), 233-239.

[81] A.W. Rijneveld, M. Levi, S. Florquin, P. Speelman, P. Carmeliet and T. van der Poll, The Journal of Immunology 168 (2002), 3507-3511.

[82] A.L. Roldan, M.V. Cubellis, M.T. Masucci, N. Behrendt, L.R. Lund, K. Danø, E. Appella and F. Blasi, The EMBO Journal 9 (1990), 467-474.

[83] E. Rønne, N. Behrendt, V. Ellis, M. Ploug, K. Danø and G. Høyer-Hansen, FEBS Lett 288 (1991), 233-236.

[84] E. Rønne, H. Pappot, J. Grøndahl-Hansen, G. Høyer-Hansen, T. Plesner, N.E. Hansen and K. Danø, Br J Haematol 89 (1995), 576-581.

[85] U.V. Schneider, R.L. Nielsen, C. Pedersen and J. EugenOlsen, BMC Infectious Diseases 7 (2007), I34.

[86] C. Selleri, N. Montuori, P. Ricci, V. Visconte, M.V. Carriero, N. Sidenius, B. Serio, F. Blasi, B. Rotoli, G. Rossi and P. Ragno, Blood 105 (2005), 2198-2205.

[87] S. Shetty, A. Kumar and S. Idell, Mol Cell Biol 17 (1997), 1075-1083.

[88] N. Sidenius and F. Blasi, FEBS Letters, 470 (2000), 40-46.

[89] N. Sidenius, C.F.M. Sier, H. Ullum, B.K. Pedersen, A.C. Lepri, F. Blasi and J. Eugen-Olsen, Blood 96 (2000), 40914095.

[90] N. Sidenius, C.F.M. Sier and F. Blasi, FEBS Letters, 475 (2000c), 52-56.

[91] N. Sidenius, A. Andolfo, R. Fesce and F. Blasi, The Journal of Biological Chemistry 277 (2002), 27982-27990.

[92] C.F. Sier, R. Stephens, J. Bizik, A. Mariani, M. Bassan, N. Pedersen, L. Frigerio, A. Ferrari, K. Dano, N. Brunner and F. Blasi, Cancer Res 58 (1998), 1843-1849.

[93] C.F. Sier, N. Sidenius, A. Mariani, G. Aletti, V. Agape, A. Ferrari, G. Casetta, R.W. Stephens, N. Brünner and F. Blasi, Lab Invest 79 (1999), 717-722.

[94] R.G. Sitrin, P.M. Pan, H.A. Harper, R.F. Todd III, D.M. Harsh and R.A. Blackwood, The Journal of Immunology 165 (2000), 3341-3349.

[95] E.M. Sloand, Blood 105 (2008), 1847-1848.

[96] O. Slot, N. Brunner, H. Locht, P. Oxholm and R.W. Stephens, Ann Rheum Dis 58 (1999), 488-492.

[97] H. Solberg, J. Rømer, N. Brünner, A. Holm, N. Sidenius, K. Danø and G. Høyer-Hansen, Int J Cancer 58 (1994), 877881.

[98] E. Soravia, A. Grebe, L.P. De, K. Helin, T.T. Suh, J.L. Degen and F. Blasi, Blood 86 (1995), 624-635.

[99] C. Speth, I. Pichler, G. Stöckl, M. Mair and M.P. Dierich, Immunobiology 199 (1998), 152-162.

[100] R.W. Stephens, A. Pedersen, H.J. Nielsen, M. Hamers, G. Høyer-Hansen, E. Rønne, E. Dybkjær, K. Dan $\varnothing$ and N. Brünner, Clin Chem 43 (1997), 1868-1876.

[101] R.W. Stephens, H.J. Nielsen, I.J. Christensen, O. ThorlaciusUssing, S. Sorensen, K. Dano and N. Brunner, J Natl Cancer Inst 91 (1999), 869-874.

[102] M.C. Strehlow, S.D. Emond, N.I. Shapiro, A.J. Pelletier and C.A. Camargo Jr., Ann Emerg Med 48 (2006), 326-331.

[103] K. Wahlberg, G. Høyer-Hansen and B. Casslén, Cancer Res 58 (1998), 3294-3298.

[104] D.A. Waltz and H.A. Chapman, The Journal of Biological Chemistry 269 (1994), 14746-14750.

[105] Y. Wang, J. Dang, L.K. Johnson, J.J. Selhamer and W.F. Doe, Eur J Biochem 227 (1995), 116-122.

[106] Y. Wang, J. Dang, H. Wang, H. Allgayer, G.A. Murrell and D. Boyd, Eur J Biochem 267 (2000), 3248-3254.

[107] Y. Wei, D.A. Waltz, N. Rao, R.J. Drummond, S. Rosenberg and H.A. Chapman, The Journal of Biochemistry 269 (1994), 32380-32388.

[108] Y. Wei, X. Yang, Q. Liu, J.A. Wilkins and H.A. Chapman, $J$ Cell Biol 144 (1999), 1285-1294.

[109] Y. Wei, J.A. Eble, Z. Wang, J.A. Kreidberg and H.A. Chapman, Mol Biol Cell 12 (2001), 2975-2986.

110] O.G. Wilhelm, S. wilhelm, G.M. Escott, V. Lutz, V. Magdolen, M. Schmitt, D.B. Rifkin, E.L. Wilson, H. Graeff and G. Brunner, Journal of Cellular Physiology 180 (1999), 225235.

[111] P. Wittenhaugen, G. Kronborg, N. Weis, H. Nielsen, N. Obel, S.S. Pedersen and J. Eugen-Olsen, European Society of Clinical Microbiology and Infectious Diseases 10 (2004), 409415.

[112] C. Yuan and M. Huang, Cell Mol Life Sci 64 (2007), 10331037.

[113] C. Østergaard, T. Benfield, J.D. Lundgren and J. EugenOlsen, Scand J Infect Dis 36 (2004), 14-19. 


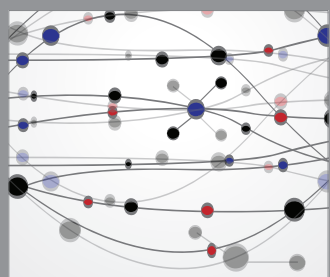

The Scientific World Journal
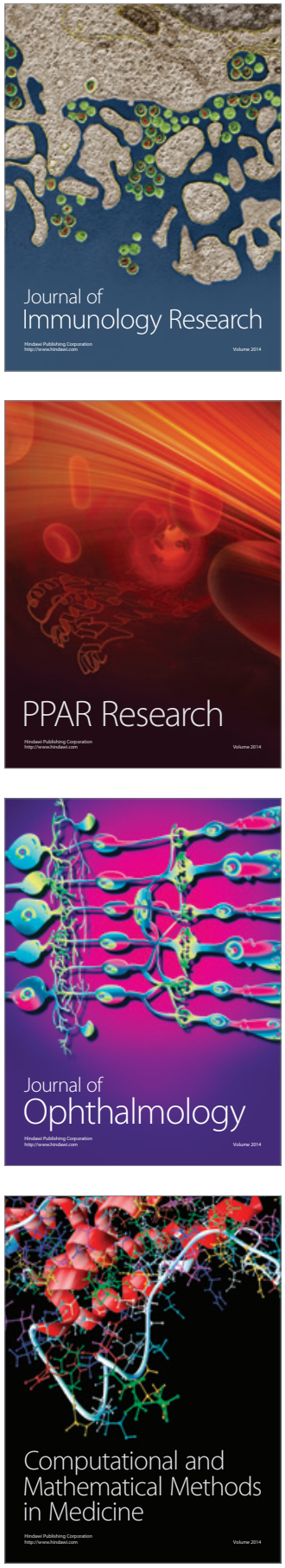

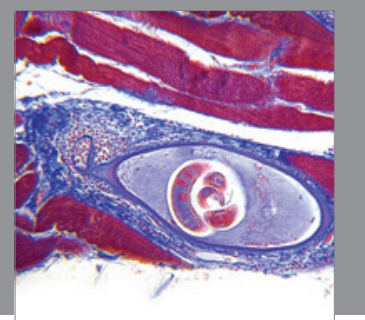

Gastroenterology

Research and Practice
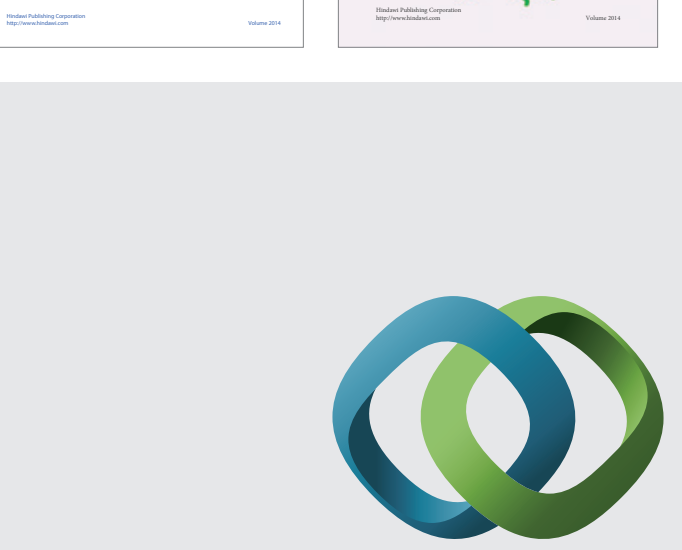

\section{Hindawi}

Submit your manuscripts at

http://www.hindawi.com
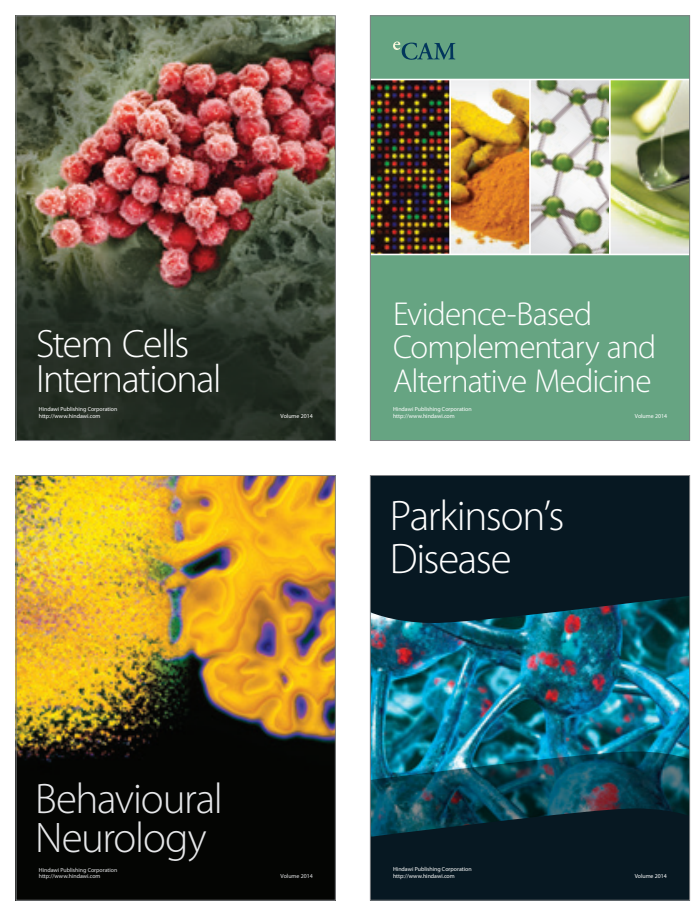

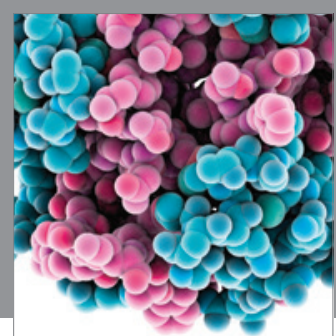

Journal of
Diabetes Research

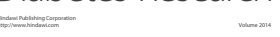

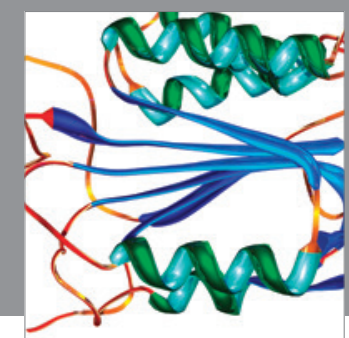

Disease Markers
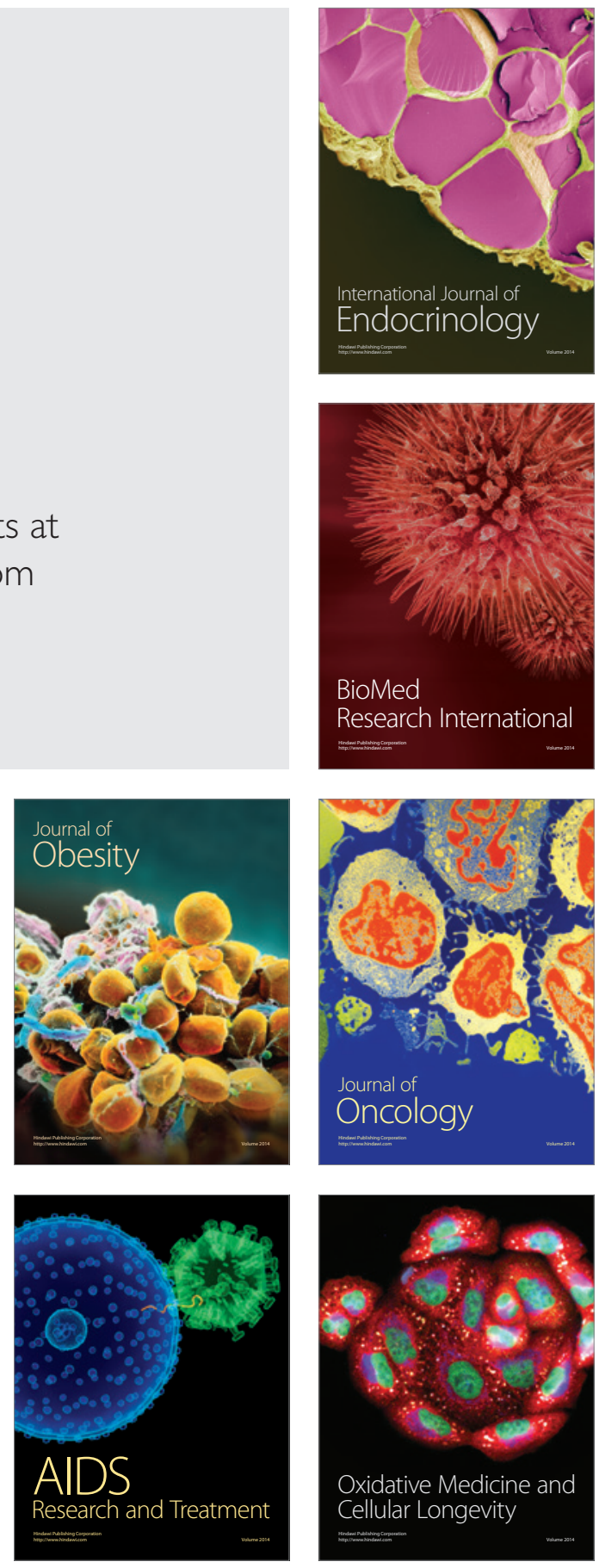